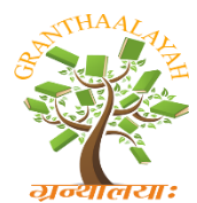

\author{
INTERNATIONAL JOURNAL OF RE
GRANTHAALAYAH \\ A knowledge Repository
}

Science

\title{
EFFECTS OF SILICON AND SEED MICROBIOLIZATION WITH BACILLUS METHYLOTROPHICUS AGAINST LEAF SPOT (CURVULARIA LUNATA) IN RICE
}

\author{
Ivaneide de Oliveira Nascimento ${ }^{1}$, Antônia Alice Costa Rodrigues ${ }^{* 1}$, Letycya Cristina \\ Barbosa Vieira ${ }^{1}$, Francisco de Assis dos Santos Diniz, Mônica Shirley Brasil dos Santos \\ Silva ${ }^{1}$, José de Ribamar Muniz Campos Neto ${ }^{1}$ \\ ${ }^{1}$ Programa de Pós Graduação em Agroecologia, Universidade Estadual do Maranhão, Campus \\ São Luís, São Luís, Maranhão, Brasil
}

\begin{abstract}
The objective of the research was to evaluate the effect of the silicified fertilization of the seeds microbiolization with B. methylotrophicus in the control of leaf spot caused by C. lunata and in the factors of rice production. The experiment was carried out in a greenhouse, in a completely randomized design, in a $5 \times 2$ factorial arrangement, with five doses of silicon $(0.0,1.0,2.0,4.0$ and $6.0 \mathrm{t}$ ha 1) and microbiolized and non-microbiolized seeds, with five repetitions. The leaf spot was evaluated at 7, 14 and 21 days after inoculation of the pathogen, considering total number of leaves, number of healthy and diseased leaves per vase, percentage of diseased leaves, size of lesion and control. The photosynthetic rates and chlorophyll indexes in rice leaves were also measured before and after inoculation of the pathogen. At the end of the crop cycle, the size and number of panicles per pot, the grains number, the number of full grains and pips per panicle and the dry plant mass were evaluated. There was an effect of the doses of agrosilicon in the control of leaf spot and in the reduction of the number and percentage of diseased leaves. However, no effect of seed microbiolization was observed on leaf spot control as well as rice production factors.
\end{abstract}

Keywords: Oryzae Sativa Agrosilício; Biological Control; Leaf Spot.

Cite This Article: Ivaneide de Oliveira Nascimento, Antônia Alice Costa Rodrigues, Letycya Cristina Barbosa Vieira, Francisco de Assis dos Santos Diniz, Mônica Shirley Brasil dos Santos Silva, José de Ribamar Muniz Campos Neto (2020). "EFFECTS OF SILICON AND SEED MICROBIOLIZATION WITH BACILLUS METHYLOTROPHICUS AGAINST LEAF SPOT (CURVULARIA LUNATA) IN RICE." International Journal of Research - Granthaalayah, 8(1), 203-212. https://doi.org/10.29121/granthaalayah.v8.i1.2020.268.

\section{Introduction}

Most species of Curvularia is known as saprophytes, but a significant number of species have been reported as phytopathogenic, mainly in grasses, in regions of tropical and subtropical 
ISSN- 2350-0530(O), ISSN- 2394-3629(P)

Index Copernicus Value (ICV 2018): 86.20

DOI: 10.5281/zenodo.3633222

climate (Sivanesan 1987). These fungi, which belong to the family Dematiaceae, are considered mitosporic. In addition, the occurrence of the Curvularia lunata (Wakker) Boedijn Meyerno fungus in rice is associated with the grain spot.

There are few reports of the occurrence of leaf spot caused by this genus, the first report of leaf spots caused by $C$. lunata in rice was carried out in Punjab, Pakistan (Majeed et al., 2016). At Maranhao there is no official survey on the damages of this disease in the rice field crop. However, due to the climatic conditions of Maranhão, there is a predominance of $C$. lunata causing leaf spot (Silva et al., 2014).

The biotic factors affect rice productivity, among which are the fungi, which cause considerable diseases and losses in the crop. Another aspect related to rice productivity problems is the soil condition, as the tropical soils are extremely weathered, acidic, with high leaching potential, low base saturation, exchangeable silicon and low silica / Fe and $\mathrm{Al}$ sesquioxides ratio, and as such have low available silicon supply capacity (Brady, 1992). In addition, agricultural practices, which have increased global food supply, have had negative impacts on the environment and ecosystem services, leading to the need for sustainable agricultural methods (Tilman et al., 2002). In this context, silicate fertilization combined with the use of microorganisms in the control of diseases and better nutrition of the plants, can be a viable alternative to be inserted in the rice crop management. In Brazil, there are products of natural origin or coming from the steel industry, which can be potentially used as a source of silicon for plants and especially for grasses (Ramos et al., 2008).

Silicon is soluble in both soils and fertilizers, and its absorption brings numerous benefits, especially for rice, which shows the agronomic essentiality of this element for the sustainable increase of crop production (Barbosa Filho et al., 2000). The most significant effect of silicon on plants, in addition to improving their performance under adverse environmental conditions, is to increase plant productivity, as well as resistance to pest attack and disease prevention (Ch et al., 2016). Silicon has a beneficial effect on chlorophyll (Silva et al., 2012) and is associated with plant resistance to biotic and abiotic factors and resistance to water stress (Korndorfer, 2006). When plants are grown in environments with high levels of soluble silicon, the element is absorbed and deposited in the intercellular space of the epidermis, forming a layer of silica gel that constitutes a barrier to the penetration by fungal hyphae. Studies show that silicon-mediated resistance against pathogens is also associated with the accumulation of phenolic compounds and phytoalexins, in addition to the activation of some PR genes (Rodrigues \& Datnoff, 2005).

The combination of the use of silicon sources with bacteria is another sustainable alternative in disease control. The main growth promoting bacteria used in biocontrol are found among nonfluorescent and fluorescente Pseudomonas spp., Bacillus, Streptomyces, Rhizobium, Brady rhizobium, Acetobacter and Herbaspirilum, Agrobacterium radiobacter, Enterobacter cloacaee and Burkholderia cepacia, among others (Mariano et al. 2004). The genus Bacillus is distinguished by the formation of endospores and multiplicity of antagonistic mechanisms, allowing its long maintenance and survival in specific ecological niches, with great versatility in the mechanisms of action to circumvent the defenses of phytopathogens (Lana Filho et al., 2010). These bacteria present several mechanisms such as: antibiosis, enzyme production, siderophores and antibiotics, which potentiate them as biocontrollers. Bacteria of the B. methylotrophicus species are gram- 
positive and interact well with plants, have high amounts of guanine and low cytokinin content, excellent biological control, plant growth promotion and bioremediation. They are still producing bacterocins which potentiate them for use as a plant protection agent (Tumbarski et al., 2015). Sustainable agriculture requires the use of strategies to increase food production without harming the environment and health, within the economic, social and political context of each region (Mariano et al., 2004). In this sense, the present research sought to evaluate the effect of silicate fertilization associated with the seeds microbiolization with $B$. methylotrophicus isolates in the control of leaf spot caused by $C$. lunata, as well as on rice production components.

\section{Material and Methods}

The experiment was conducted in a greenhouse at the Maranhao State University, with the use of BRS Primavera variety rice seeds. The seeds were sown in autoclaved soil in $3 \mathrm{~kg}$ pots. A completely randomized design with $5 \times 2$ factorial arrangement, five silicon doses $(0.0,1.0,2.0$, 4.0 and $6.0 \mathrm{t} \mathrm{ha}^{-1}$ ) was used, and two types of treatments in the seeds: microbiolized seeds with solution of Bacillus methylotrophicus (isolates B12 and B41) and non microbiolized seeds, with five repetitions.

The soil used was free sand and contained $10 \mathrm{~g} \mathrm{dm}{ }^{3} \mathrm{MO}, \mathrm{pH}=4.3, \mathrm{P}=4.0 \mathrm{mg} \mathrm{dm}{ }^{3}, \mathrm{~K}=$ $3.5 \mathrm{mmol}_{\mathrm{c}} \mathrm{dm}^{3}, \mathrm{Ca}=12 \mathrm{mmol}_{\mathrm{c}} \mathrm{dm}^{3}, \mathrm{Mg}_{\mathrm{c}}=10 \mathrm{mmol} \mathrm{dm}^{3}, \mathrm{Al}+\mathrm{M}_{\mathrm{c}}=23 \mathrm{mmol} \mathrm{dm}^{3}, \mathrm{SB}_{\mathrm{c}}=$ $25.5 \mathrm{mmoldm}^{3}, \mathrm{CTC}={ }_{\mathrm{c}} 48.5 \mathrm{mmol} \mathrm{dm}{ }^{3}, 53 \%$ and $\mathrm{V}=1.5 \mathrm{mg}^{\mathrm{dm}-3}$ silicon. After 40 days before planting, fertilization was performed silicate (Agrosilício: $\mathrm{Ca} 25 \%, 6 \% \mathrm{Mg}$ and $10.5 \% \mathrm{Si}$ ) and lime (dolomitic limestone $32 \% \mathrm{CaO}, 15 \% \mathrm{MgO}, 80 \%$ of PN and $90 \%$ of PRNT). Based on the levels of $\mathrm{Ca}, \mathrm{Mg}$ and $\mathrm{Si}$ present in agrosilicon, $1500 \mathrm{~kg} \mathrm{ha}^{-1}$ of $\mathrm{Ca}$ and $360 \mathrm{~kg} \mathrm{ha}^{-1}$ of $\mathrm{Mg}$ were applied at a dose of $6.0 \mathrm{tha}^{-1}$. To balance the levels of $\mathrm{Ca}$ and $\mathrm{Mg}$ in all experimental units and isolate the effect of silicon released by agrosilício product was applied dolomite limestone, since limestone and agrosilicon used are sources of $\mathrm{Ca}$ and $\mathrm{Mg}$.

The bacterial isolates B12 and B41 of B. methylotrophicus, used in the microbiolization of rice seeds, were identified molecularly and are part of the biological collection of the Phytopathology Laboratory of the Maranhao State University. They are kept refrigerated by three preservation methods: in BDA culture medium (Potato, Dextrose, Agar); in autoclaved mineral oil and in sterile distilled water (Castellani method).

In the microbiolysis process of the rice seeds, the bacteria were multiplied in BDA culture medium and conditioned in BOD for growth for 48 hours at $28^{\circ} \mathrm{C}$ and photoperiod of 12 hours. Subsequently, bacterial suspensions of each isolate were prepared, and their concentrations determined at $10^{8} \mathrm{CFU} / \mathrm{ml}$ in a spectrophotometer with wavelength of $540 \mathrm{~nm}$ and absorbance of 0.5. In the suspension prepared with the mixture in equal proportions of the two bacteria, the seeds were immersed in the suspensions and homogenized on a shaker table at $100 \mathrm{rpm}$ for 1 hour. After the agitation, the seeds were planted.

At the planting, $200 \mathrm{~kg} \mathrm{ha}^{-1}$ of the formulation of 5-30-15 (N-P-K) recommended for rice cultivation was applied according to soil analysis. Ten seeds per pot were sown after the second leaf was released (V2 stage), thinning was performed, leaving six plants per pot. 
The inoculation of the pathogen was carried out after 21 days of cultivation of the rice plants. The inoculated spores were obtained from pure colonies of C. lunata, after seven days of incubation. The concentration of the suspension was calculated in Neubauer's chamber, which was adjusted to a concentration of $1 \times 10^{5}$ conidia $\mathrm{mL}^{1}$. The plants were kept in a humid chamber for 48 hours before and 48 hours after inoculation.

Leaf spot on rice caused by $C$. lunata was evaluated at 7, 14 and 21 days after inoculation of the pathogen, the average of the three evaluations was considered for leaves/pot number, number of healthy leaves/ pot, number of leaves sick leaves/pot, percentage of diseased leaves, lesion size and percentage of control.

In the $24 \mathrm{~h}$ before inoculation of the pathogen, $120 \mathrm{~h}$ and $168 \mathrm{~h}$ after inoculation, the photosynthetic rate and the chlorophyll index in five rice leaves per treatment were measured from 7:30 a.m. to 9:30 a.m., through IRGA (LI 6400 XT, Portable Photo synthesis System) in the amount of light of $1800, \mathrm{CV}$ below 1, with the values of conductance, internal carbon and transpiration positive. To measure the chlorophyll index, the SPAD (Soil Plant Analysis Development) was used in the greener leaves. The readings were taken at four points of each leaf, using the average of the readings.

The production parameters were evaluated at the end of crop cycle, where the panicle size was measured with a millimeter ruler, number of grains per panicle, number of full grains and pips, and the mass of the dried plants in an oven with forced air circulation, at a temperature of $50{ }^{\circ} \mathrm{C}$. Data were submitted to analysis of variance and regression. The models were chosen based on the biological phenomenon, the significance of the regression coefficients (using the level of up to $10 \%$ probability), the " $\mathrm{t}$ " test, and the determination coefficient (R2 = SSRegression / SSTreatment). The comparison of the means of all variables evaluated between microbiolized seeds and non-microbiolized seeds was performed by the $\mathrm{F}$ test at the $5 \%$ probability level. Statistical analysis was performed using the statistical program Sisvar (version 5.6, 2008) (Ferreira, 2008).

\section{Results and Discussion}

Significant interaction between seed microbiolization and silicon doses in rice cultivation was observed on leaf sickle size ( $\mathrm{PFD}, \mathrm{P}=0.0242$ ), number of grain per panicle $(\mathrm{NGP}, \mathrm{P}=0.0354$ ) and dry plant mass (MPS, $\mathrm{P}=0.0063$ ), the interaction was studied considering the doses of agrosilicon within microbiolized and non-microbiolized seed types.

There was no significant interaction between bacterial microbiolization of seeds and silicon doses on the number of leaves per pot (L/pot, $\mathrm{P}=0.1063$ ), number of healthy leaves per pot. (HL/pot, $\mathrm{P}$ $=0.2553)$, percentage of diseased leaves per pot $(\mathrm{DL} / \mathrm{pot}, \mathrm{P}=0.8324)$, lesion size $(\mathrm{LZ}=0.7107)$, percentage of leaf spot control (LSC, $\mathrm{P}=0, \mathrm{P}=0.1563$ ), chlorophyll index before and after of pathogen inoculation ( $\mathrm{CIB}, \mathrm{P}=0,2378, \mathrm{CIA}, \mathrm{P}=0.0855$ ), photosynthetic rate before and after of pathogen inoculation ( $\mathrm{PRB}, \mathrm{P}=0.8434$, $\mathrm{PRA}, \mathrm{P}=0.0687)$, panicle size $(\mathrm{PZ}, \mathrm{P}=0.2204)$, number of full and empyt grains per panicle (Num. FG, $\mathrm{P}=0.2026$; Num. $\mathrm{EG}, \mathrm{P}=0.1221$ ). Therefore, the effect of agrosilicon doses and microbiolization of rice seeds was studied. 
The doses of agrosilicon had no effect on the number of leaves per pot with a mean value of 26.88 leaf / pot and number of healthy leaves per pot with 22.75 leaves / pot, since no adjustment model was found for any regression. On the other hand, the effect of the doses of agrosilicon on the number of diseased leaves and percentage of diseased leaves per vase, which adjusted to the decreasing quadratic regression, was observed to be 0.1637 and 0.265 of the number and percentage of diseased leaves for each ton of applied agrosilicon, respectively (Figure 1A and 1B).
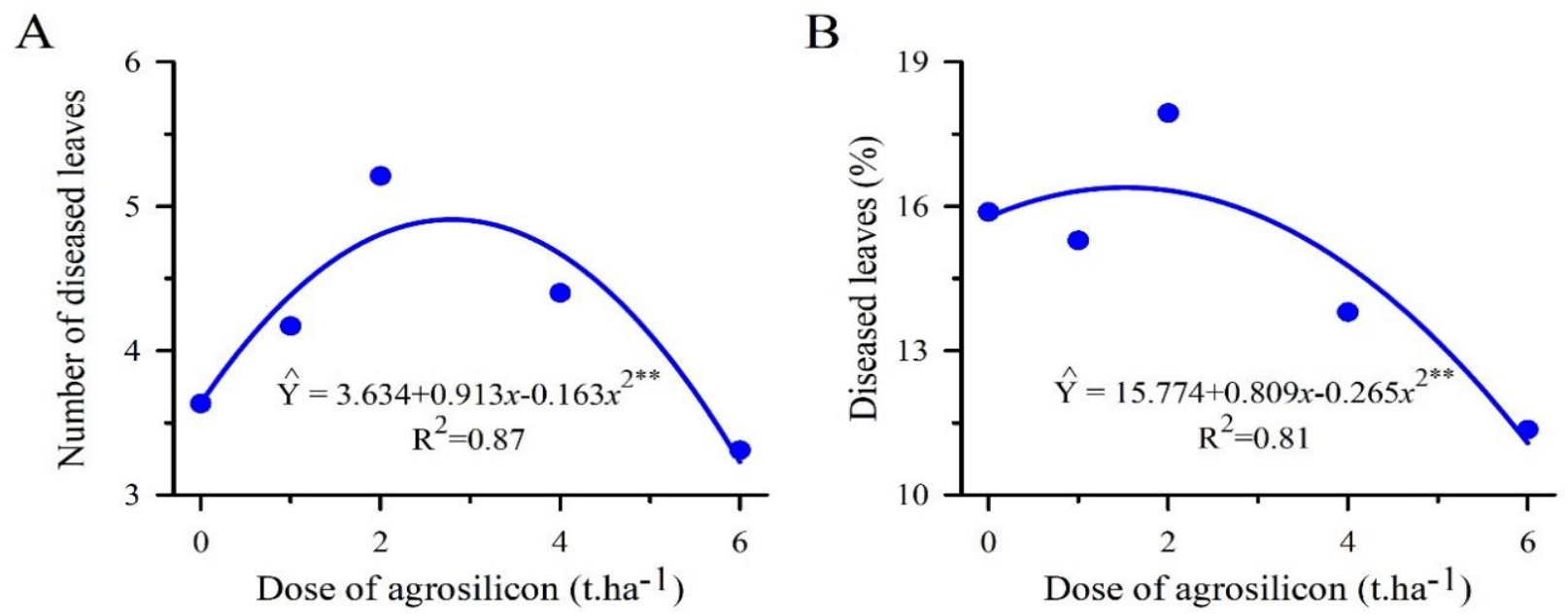

**: Significant at the $1 \%$ probability level, by the "f" test.

Figure 1: Number of diseased leaves (A), and Percentage of diseased leaves (B) as a function of doses of agrosilicon.

According to the results, there was an effect of agrosilicon doses on the control of leaf spot caused by C. lunata, adjusted to the decreasing quadratic regression $(\hat{Y}=18,618512+41,975545 \mathrm{X}$ $5,298501 * \mathrm{X}^{2} ; \mathrm{R}^{2}=0,71$ ), there was a reduction of 5.29 in the disease control percentage for each ton of applied agroforestry, respectively. It can be inferred that the smaller dosages of agrosilicon provided greater control of the leaf spot caused by $\mathrm{C}$. lunata. The mechanism of disease resistance is attributed to the association of silicon with constituents of the cell wall, making them less accessible to the degradation enzymes produced by the pathogen. Nevertheless, there are researchers who argue that this element, besides the purely mechanical effect, also plays a role of systemic protection against fungi (Barbosa Filho et al., 2000).

There was no effect of soil silicon application on the chlorophyll index in rice leaves, without and with biotic stress. With average values of 32.27 and 29.05 for the index of chlorophyll in rice leaves, without and with biotic stress, respectively. The results found in the experiment performed follow the pattern obtained by Faria Junior et al. (2009), when they verified that the Si doses, did not influence the chlorophyll index, in cultivars of rice under doses of silicon. in addition to the results of Freitas et al. (2013), who reported that silicon does not contribute to the increase of the chlorophyll content of upland rice plants under aluminum stress, contrary to the hypothesis that silicon has a beneficial effect on chlorophyll. Oliveira et al. (2016), in an experiment with upland rice submitted to silicate fertilization and soil water stresses, concluded that silicate fertilization influenced the chlorophyll index in rice leaf under greenhouse conditions. Several external and internal factors affect the chlorophyll biosynthesis; therefore, its foliar contents can vary significantly (Santos et al., 2010). 
There was no effect of the doses of agrosilicon on the photosynthetic rate in leaves with and without biotic stress. The photosynthetic rates prior to pathogen inoculation $(\bar{X}=3,61)$ and after pathogen inoculation $(\bar{X}=5,62)$ did not fit any regression equation. However, in a study conducted by Paula et al. (2015), in soil treatment with zinc and silicon, promoted a significant increase in the net rate of photosynthesis in maize.

Agrosilicic dosages had no effect on the factors of production, such as panicle size $(\bar{X}=16,06)$, number of grains per panicle ( $\bar{X}=35,54)$, number of full grains $(\bar{X}=17,34)$ and number of empty grains $(\bar{X}=18,45)$, since these four factors did not fit the regression models.

Despite the significant interaction between the agrosilicic dosages and the microbiolization of the seeds on the dry plant mass, number of grains per panicle and leaf size of diseased rice were verified. However, there was no effect of silicon doses on dry plant mass and number of grains per panicles from microbiolized and non microbiolized seeds, as they did not fit the regression models. Concerning the size of the diseased leaf from plants cultivated with non-microbiolized seeds, there was an effect of agrosilicon doses with adjustment to increasing quadratic regression $\left(\hat{Y}=9,6238+2,1076 X-0,2484 * X^{2} ; R^{2}=0,98\right)$. However, in plants with microbiolized seeds, the doses of agrosilicon showed no effect on leaf size, did not fit any model of regression equation.

The results obtained in the present work indicate that the application of silicon in the soil provided control in the leaf spot caused by $C$. lunata and did not increase the production factors (panicle size, number of grains per panicle and number of full and empty grains per panicle) and did not increase the chlorophyll index or the photosynthetic rate. This is consistent with the effects of silicon application on the soil, since the importance of silicate fertilization to the plants is mainly related to the increase of productivity, through several indirect actions, such as increase of the resistance of the fabric and promotion of plants with better performance due to leaf position and light interception, and improved plant architecture and increased photosynthesis (Lana et al., 2003, Donegá, 2009).

On the other hand, silicate fertilization also improves the physical, physicochemical and chemical soil unfavorable conditions, contributing directly to the nutrition, increasing the resistance to pests and pests in a large number of plants (Castro, 2009). soil, present similar behavior to calcium and magnesium carbonates, promoting chemical reactions similar to those caused by limestone, such as: $\mathrm{pH}$ increase, toxic $\mathrm{Al}$ and $\mathrm{Mn}$ precipitation, increase exchangeable $\mathrm{Ca}$ and $\mathrm{Mg}$ contentes, and bases saturation and reduction in Al-saturation, as well as providing additional benefit of increasing Si levels in soil (Epstein, 1999; Savant et al., 1999). It also increases the concentration of $\mathrm{P}$ in the soil by displacing the $\mathrm{P}$ fixed in the Fe and $\mathrm{Al}$ oxides, through the saturation of the $\mathrm{P}$ absorption sites (Prado \& Fernandes 2001).

Among the reasons that promoted reduction in the number and percentage of diseased leaves and control of leaf spot with the application of silicon on the spring rice variety, it is possible to mention the silicon content in the soil used in the experiment, since it has $1,5 \mathrm{mg} \mathrm{dm}^{-3}$ of silicon, a content responsive to the application of calcium silicate, magnesium and silicon in the soil, according to Korndorfer et al. (2001), sandy soils with silicon values lower than the range of 6 to $8 \mathrm{mg} \mathrm{dm}^{-3}$ extracted in $0.01 \mathrm{~mol} \mathrm{~L}^{-1} \mathrm{CaCl}_{2}$ often respond to the application of silicates. Another important 
point to consider is the rice variety used in the experiment because it is an improved cultivar, indicated for the upland planting system, responds to the application of silicon in the soil. Highland rice plants absorb and accumulate high amounts of silicon (Pereira et al., 2007).

There was no effect of the microbiolization of the seeds on the chlorophyll index before and after inoculation of the pathogen, photosynthetic rate before and after inoculation of the pathogen, panicle size, number of full and empty grains per panicle in rice plants (Table 1). Similar results were obtained by Ludwig et al. (2013), in which Bacillus sp. species did not provide gains in relation to the growth of rice plants. In another study, Ludwig et al. (2009) observed that the microbiolization of rice seeds with Bacillus sp. and Bacillus subtilis reduced the number of empty grains. Bacillus species can enhance plant growth by increasing plant hormone levels, such as auxins and gibberellins, favoring the availability of phosphate in the soil (Pane et al., 2012). In this case, in which the plants were infected by a pathogen, growth promotion is indirect (Mariano et al., 2004) and energy demand may occur to control the disease and not favor the growth of the plant.

Table 1: Mean values of rice agronomic variables BRS Primavera, microbiolized with $B$. methylotrophicus

\begin{tabular}{|l|l|l|l|l|l|l|l|}
\hline Microbiolization & \multicolumn{7}{|c|}{ Agronomic variables } \\
\cline { 2 - 8 } & CIB & CIA & PRB & PRA & PZ(cm) & N.FG & N.EG \\
\hline With & $31.72 \mathrm{a}$ & $28.77 \mathrm{a}$ & $3.97 \mathrm{a}$ & $5.65 \mathrm{a}$ & $16.52 \mathrm{a}$ & $18.13 \mathrm{a}$ & $18.74 \mathrm{a}$ \\
\hline Without & $32.83 \mathrm{a}$ & $29.33 \mathrm{a}$ & $3.25 \mathrm{a}$ & $5.58 \mathrm{a}$ & $15.61 \mathrm{a}$ & $16.54 \mathrm{a}$ & $18.16 \mathrm{a}$ \\
\hline VC $(\%)$ & 15.65 & 19 & 25.07 & 20.05 & 10.84 & 29.32 & 25.22 \\
\hline$P$ & 0.8383 & 0.4665 & 0.3104 & 0.8565 & 0.0612 & 0.2753 & 0.6548 \\
\hline
\end{tabular}

$* \mathrm{CIB}=$ chlorophyll content before pathogen inoculation; CIA = chlorophyll content after pathogen inoculation; $\mathrm{PRB}=$ photosynthetic rate prior to pathogen inoculation; PRA = photosynthetic rate after pathogen inoculation; $\mathrm{PZ}=$ panicle size; $\mathrm{N} . \mathrm{FG}=$ number of full grains; $\mathrm{N} . \mathrm{EG}=$ number of empty grains.

The seeds microbiolization with isolates of $B$. methylotrophicus did not have an effect on the resistance of the variety Primavera to Leaf Spot, because there was no significant difference by the $\mathrm{F}$ test at $5 \%$ probability of the microbiolization on the number of leaves per pot, number of healthy leaves per pot, number of diseased leaves per pot, percentage of diseased leaves per pot, size of lesion and control of leaf spot (Table 2).

These results contradict those found by Silva et al. (2014), who in an experiment on the leaf spot biocontrol in Bonança rice, observed that seven Bacillus isolates controlled this disease, especially the species of B. cereus and Bacillus sp. There are still few researches using Bacillus bacteria in the control of leaf spot caused by $C$. lunata, since this fungus is associated with the grain spot, but in the Maranhao conditions it has been common to observe symptoms similar to the Brown Spot, but that in the fungus isolation the occurrence is of Curvularia lunata.

Therefore, it is recommended to carry out new research in a greenhouse and field without the association with silicate fertilization, which would raise the gaps and further substantiate the application of Bacillus in the control of this disease. Bacteria of the B. methylotrophicus species 
interact well with plants, have a high amount of guanine and a low cytokinin content, excellent activity in biological control, in the promotion of plant growth and in bioremediation. They are still producing bacterocins which potentiate them for use as a plant protection agent (Tumbarski et al., 2015). Reinforcing the action of plant protectors, in a study by Suprapta et al. (2016), the performance of $B$. methylotrophicus as resistance inducing agent against blast disease caused by Pyricularia oryzae Cav. in Bali local rice variety, Padi MerahPutih Medang.

Table 2. Mean values of leaf spot resistance of microbiolized rice plants with $B$. methylotrophicus.

\begin{tabular}{|c|c|c|c|c|c|c|}
\hline Microbiolization & N.L/ pot & N.HL/pot & N.DF/pot & \begin{tabular}{|l|}
$\%$ D.L \\
\end{tabular} & D.L $\left(\mathrm{cm}^{-2}\right)$ & Control (\%) \\
\hline With & $27.72 \mathrm{a}$ & $23.19 \mathrm{a}$ & $3.87 \mathrm{a}$ & $14.49 \mathrm{a}$ & $0.039 \mathrm{a}$ & $85.51 \mathrm{a}$ \\
\hline Without & $27.04 \mathrm{a}$ & $22.31 \mathrm{a}$ & $4.42 \mathrm{a}$ & $15.21 \mathrm{a}$ & $0.037 \mathrm{a}$ & $83.36 \mathrm{a}$ \\
\hline $\mathrm{VC}(\%)$ & 12.26 & 13.61 & 32.87 & 31.6 & 60.2 & 5.61 \\
\hline$P$ & 0.73 & 0.3195 & 0.16 & 0.39 & 0.78 & 0.12 \\
\hline
\end{tabular}

$*$ N. L = Number of leaves; N. HL/pot = Number of healthy leaves per pot; N.DF/pot = Number of diseased leaves per pot; \%D. L = percentage of diseased leaves; S.L = Size Leaves.

\section{Conclusion}

There was an effect of the doses of agrosilicon on the control of leaf spot caused by $C$. lunata and on the reduction of the number and percentage of diseased leaves. However, it had no effect on panicle size, number of grains per panicle, number of grains full and empty per panicle.

There was no effect of microbiolization with B. methylotrophicus on control of leaf spot caused by $C$. lunata, and neither on the photosynthetic rate, panicle size, number of grains full and empty in Primavera rice.

\section{References}

[1] Sivanesan, A. Graminicolous species of Bipolaris, Curvularia, Drechslera, Exserohilum and their teleomorphs. Mycological Papers, 158, 1987, 1-261.

[2] Majeed, RA., Shahid, AA.; Ashfaq, M., Saleem, MZ., Haider, MS. First Report of Curvularia lunata Causing Brown Leaf Spots of Rice in Punjab, Pakistan. Plant Disease, 100(1), 2016, 21.

[3] Silva, MSBS. et al. Sanidade de sementes de arroz, biocontrole, caracterização e transmissão de Curvularia lunata em sementes-plântula de arroz. Revista Ceres, 61(4), 2014, 511-517.

[4] Brady, NC. The nature and properties of soils. 10.ed. New York: Macmillan, 750p., 1992.

[5] Tilman, D. et al. Agricultural sustainability and intensive production practices. Nature, 418, 2002, 671-672.

[6] Ramos, LA., Korndörfer, GH. e Nolla, A. acúmulo de silício em plantas de arroz do ecossistema de várzea submetido à aplicação de diferentes fontes. Bragantia, 67(3), 2008, 751-757.

[7] Barbosa Filho, MP. et al. Importância do silício para a cultura do arroz (revisão de literatura). Informações Agronômicas, n. 89, 2000.

[8] Ch, CM., Kapoor, R. T. e Ganjewala, D. Alleviation of abiotic and biotic stress in plants by silicon supplementation. Scientia Agriculturae, 13(2), 2016, 59-73.

[9] Silva, ON. et al.. Silicon-induced increase in chlorophyll is modulated by the leaf water potential in two water-deficient tomato cultivars. Plant Soil Environment, 58(11), 2012, 481-486. 
[10] Korndörfer, GH. Elementosbenéficos.IN: Nutrição mineral de plantas. (ed. FERNANDES, M. S.). Viçosa, MG: Sociedade Brasileira de Ciência do solo, 2006.

[11] Rodrigues, FA. e Datnoff, LE. Silicon and rice disease management.Fitopatologia Brasileira, 30, 2005, 457-469.

[12] Mariano, RLR. et al. Importância de bactérias promotoras de crescimento e de biocontrole de doenças de plantas para uma agricultura sustentável. Anais da Academia Pernambucana de Ciências Agronômica, 1, 2004, 89-111.

[13] Lanna Filho, R., Ferro, HM. e Pinho, RSC. Controle biológico mediado por Bacillussubtilis.Revista Tropica - Ciências Agrárias e Biológicas, 4(2), 2010, 12-20.

[14] Tumbarski, Y., Petkov, E. e Denkova, Z. Study on the influence of the cultural conditions and the composition of the culture medium on the antimicrobial activity of Bacillus methylotrophicus BM47 against some fungal phytopathogens. Journal of Global Biosciences, 4(8), 2015, 2990-2996.

[15] Ferreira, DF. SISVAR: um programa para análises e ensino de estatística. Revista Symposium, Lavras, 6, 2008, 36-41.

[16] Faria júnior, L. A. et al. Produção de matéria seca, teor e acumúlo de silício em cultivares de arroz sob doses de silício. Ciência Agrotécnica, 33(4), 2009, 1034-1040.

[17] Freitas, LB., Fernandes, DM. e Maia, SCM. Índice de clorofila em plantas de arroz de terras altas submetidas a estresse por alumínio e aplicação de silício. Journal of Agronomic Sciences, 2(2), 2013, 229-241.

[18] Oliveira, JR. et al. Production and accumalation of silicone ( $\mathrm{Si}$ ) in rice plants under silicate fertilization and soil water tensions. Australian Journal of Crop Science, 10(2), 2016, 244-250.

[19] Santos, DS. et al. Eficiência de fontes de silício para a cultura do arroz. Enciclópedia Biosfera, v.6, n.11, p. 1-10, 2010.

[20] Paula, LS. et al. Silicon ( $\mathrm{Si}$ ) ameliorates the gasexchangeand reduces negative impacts on pholosynthetic pigments in maize plants under zinc ( $\mathrm{Zn}$ ) toxicity. Australia Journal of Crop Science (AJCS), 9(10), 2015, 901-908.

[21] Lana, RMQ. et al. Effect of calcium silicate on the productivity and silicon accumulation in the tomato plant. Bioscience Journal, 19, 2003, 15-20.

[22] Donegá, MA. Ratio K: Ca and application of silicon in the nutrient solution for the hydroponic cultivation of coriander. 2009. 62 f. Dissertation - High School of the Agriculture, Luiz de Queiroz, Piracicaba, 2009.

[23] Castro, GSA. Alterações físicas e químicas do solo em função do sistema de produção e da aplicação superficial de silicato e calcário. 2009.152 f. Dissertação (Mestrado em Agronomia/Agricultura) - Universidade Estadual Paulista, Botucatu, 2009.

[24] Epstein, E. Silicon. Annual Review of Plant Physiology and Plant Molecular Biology,Palo Alto, 50, 1999, 641-664.

[25] Savant, NK., Korndorfer, GH. e Datnoff, LE. et al. Silicon nutrition and sugarcane production: a review. Journal of Plant Nutrition, 22(12), 1999, 1853-1903.

[26] Prado, RM., Fernandes, F. M. Efeito da escória de siderurgia e do calcário na disponibilidade de fósforo em um Latossolo Vermelho-Amarelo cultivado com cana-de-açúcar. Pesquisa Agropecuária Brasileira, 36, 2001, 1199-1204.

[27] Korndörfer, GH. et al. Calibration of soil and plant silicone analysis for rice production. Journal of Plant Nutrition, 24(7), 2001, 1071-1084.

[28] Pereira, H.S. et al. Avaliação de fontes e de extratores de silício no solo. Pesquisa Agropecuária Brasileira, 42(2), 2007, 239-247.

[29] Ludwig, J., Moura, AB. e Gomes, CB. (Potencial da Microbiolização de sementes de arroz com rizobactérias para o biocontrole do nematóide das galhas. Tropical Plant Pathology, 38(3), 2013, 264-268.

[30] Ludwig, J. et al. Microbiolização de sementes para o controle da mancha parda e da escaldadura em arroz irrigado. Tropical Plant Pathology, 34(5), 2009, 322-328. 
DOI: 10.5281/zenodo.3633222

[31] Pane, C. et al. Novel strain of Bacillus isolatd from compost and compost-amended soils, as biological control agents against soil-borne phytopathogenic fungi. Biocontrol Science Technology., 22(12), 2012, 1373-1388.

[32] Suprapta, DN., Khalimi, K. e Darmadi, AAK. Molecular identification of local plant growth promoting rhizobacteria that act as resistance inducing agente against rice blast disease. Journal of Current Research in Science, 4(1), 2016, 1-6

*Corresponding author.

E-mail address: ivaneide_agro@yahoo.com.br/aacrodrigues@outlook.com/cris-lyty@hotmail.com/ francisco.santos.diniz1996@gmail.com/shirleybrasil.85@hotmail.com/munizneto@msn.com/ ivaneide_agro@yahoo.com.br 